
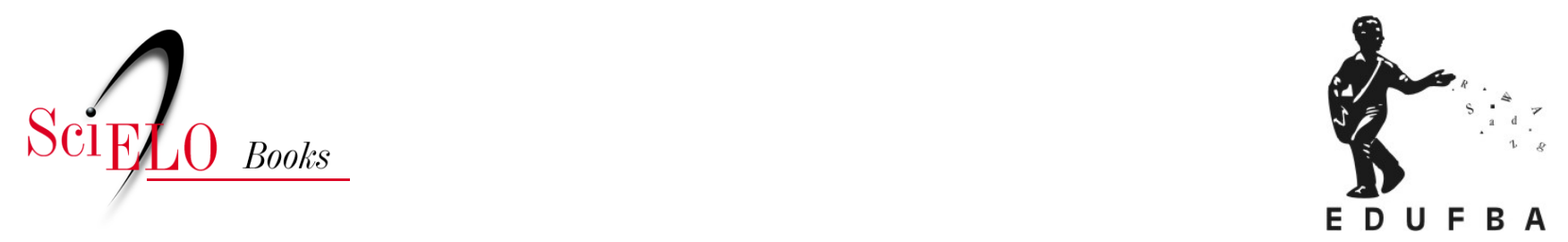

\title{
A reestruturação do setor postal brasileiro regulação, modelos organizacionais e modernização na virada do milênio (1994-2011)
}

\author{
Tadeu Gomes Teixeira
}

TEIXEIRA, T.G. A reestruturação do setor postal brasileiro: regulação, modelos organizacionais e modernização na virada do milênio (1994-2011). In: Os Correios e as políticas governamentais: mudanças e permanências [online]. Salvador: EDUFBA, 2016, pp. 65-103. ISBN: 978-85-232-2025-9. https://doi.org/10.7476/9788523220259.0005.

\section{International license.}

Todo o conteúdo deste trabalho, exceto quando houver ressalva, é publicado sob a licença Creative Commons Atribição $\underline{4.0}$. 


\section{A reestruturação do setor postal brasileiro: regulação, modelos organizacionais e modernização na virada do milênio (1994-2011)}

A ECT passou por várias transformações entre 1994 e 2011. Foram propostas e mudanças iniciadas durante o governo do presidente Fernando Henrique Cardoso e que influenciaram as decisões e estratégias para o setor postal durante os governos dos presidentes Luís Inácio Lula da Silva e Dilma Rousseff.

Nesse sentido, analisam-se neste capítulo as propostas e as mudanças ocorridas entre 1994 e 2011 na regulação do sistema postal brasileiro, no modelo organizacional da ECT e nas estratégias mercadológicas da estatal. Por fim, discute-se a relação entre política e gestão na ECT durante o período para tratar da "crise dos Correios" durante o segundo mandato do governo Lula, sendo a análise desdobrada até o governo da presidente Dilma Rousseff.

Durante o governo do Partido dos Trabalhadores (PT), quais foram as estratégias governamentais para a ECT? Em que se diferenciam das propostas do governo de Fernando Henrique Cardoso? Há continuidades ou rupturas nas estratégias para o setor postal entre 1994 e 2011?

Busca-se, assim, compreender as permanências e mudanças nas estratégias para o setor postal no período e como as estratégias políticas dos blocos no poder repercutiram nas transformações do setor. São essas questões que perpassam as discussões apresentadas neste capítulo. 


\section{O SETOR POSTAL BRASILEIRO DURANTE O GOVERNO FHC: PROPOSTA DE NOVO MODELO ORGANIZACIONAL PARA UM NOVO MARCO REGULATÓRIO}

Ao iniciar o mandato em 1994, o presidente Fernando Henrique Cardoso tomou medidas de grande impacto na ordem econômica brasileira e na estrutura de Estado. Nesse sentido, o setor de telecomunicações foi priorizado e parte das ações previstas para a área - incluindo o setor postal - foi apresentada em 1995, na primeira versão do Programa de Recuperação e Ampliação do Sistema de Telecomunicações e do Sistema Postal (PASTE).

O PASTE estabeleceu as diretrizes que seriam seguidas pelo governo Fernando Henrique Cardoso nas telecomunicações e no setor postal. Tratava-se de uma mudança planejada, inicialmente, para a modernização da infraestrutura e do sistema gerencial e, posteriormente, possível privatização dos setores, como ocorreu com as telecomunicações. São dois processos, portanto, articulados e aparentemente paradoxais: se moderniza o setor e, em seguida, o privatiza. A explicação oficial para isso, todavia, justifica a modernização antes de quaisquer medidas de privatização para viabilizar possível sobrevivência dos operadores estatais em um mercado aberto.

Os investimentos previstos no PASTE contemplavam programas, metas e projetos de recuperação e ampliação das telecomunicações e dos serviços postais. Os investimentos iniciaram-se ainda em 1995. O PASTE já previa investimentos até 1999, com a possibilidade de estendê-los até 2003. Isso significa que o governo FHC planejou reformular e reestruturar os setores como parte de seu plano de governo. As metas deveriam ser concluídas no primeiro mandato (como ocorreu com a privatização das telecomunicações em 1998) e também durante o segundo mandato (prevendo-se a reforma do setor postal).

A modernização postal estava baseada no aumento da oferta de serviços, na modernização tecnológica e na consolidação e ampliação do papel social dos Correios como agente prestador de serviços públicos. Para isso, o discurso de posse do ministro das Comunicações do primeiro mandato de FHC, Sérgio Motta, já prenunciava quais seriam as principais diretrizes do governo: 
Formulação de um amplo programa de investimentos para o período 1995/1999, com enlace até 2003, a ser executado pelas empresas do setor de comunicações - públicas e privadas - condizente com o elenco de diretrizes e metas traçadas para os serviços de telecomunicações e postais. [...]. Implementação de novo modelo institucional para o setor (postal e de telecomunicações), incentivando a competição na exploração dos serviços, com intensa participação de capitais privados e implantação do cenário de transição para privatização integral da operação do setor [...]. Modernização dos serviços postais. (BRASIL, [199?], p. 02, grifo nosso)

Os projetos apresentados na primeira versão do PASTE foram executados entre 1995 e 1997 e contemplaram planos de modernização dos Correios em três setores: mecanização da triagem, informatização das agências e racionalização da rede postal aérea noturna. Concomitante a esses investimentos para modernização da empresa, "iniciaram-se também os estudos sobre a reestruturação institucional” da ECT. (BRASIL, 1998, p. 09, grifo nosso)

O governo do presidente Fernando Henrique Cardoso justificou as propostas para o setor postal com argumentos semelhantes aos das agências multilaterais, alegando que os sistemas postais foram operados desde a década de 1960 em regime de monopólio e com controle estatal, modelo que estaria defasado. Para o governo FHC, com as transformações ocorridas na economia capitalista em decorrência do "ambiente concorrencial" dos anos de 1980 e 1990 era preciso uma "reforma" no setor postal para adequá-lo às novas circunstâncias. Esse cenário forjado a partir das transformações no processo de acumulação capitalista exigiria "[...] uma organização postal mais moderna e orientada para o mercado.” (BRASIL, 1997, p. 15)

De acordo com os planos apresentados no PASTE, o serviço postal brasileiro operava com base na lógica de território nacional, assim como os países europeus antes dos processos de liberalização. Porém, com a intensificação dos processos de globalização, o papel dos setores postais passou a ser estratégico na prestação de suporte às atividades econômicas. Essa premissa orientou a análise do governo FHC acerca do setor, que deveria, a partir de então, "orientar-se para o consumidor". 
Com isso, o setor postal brasileiro passou a ser alvo de estratégias de modernização, sobretudo em termos gerenciais, em um processo de reformulação administrativa da máquina pública a partir de instrumentos empresariais. Ao mesmo tempo, "[...] observando o grande potencial de mercado, a iniciativa privada redescobre os Correios como atividade empresarial rentável", o que faz com que "[...] a atividade postal deixe de ser atividade exclusiva do Estado e passe (a) conviver com capitais privados." (BRASIL, 1997, p. 16)

Dessa forma, verifica-se que além do projeto hegemônico neoliberal a conduzir as premissas de reforma no setor, o suposto interesse de grupos empresariais também se tornou importante, como declarou o governo de FHC. Os dois elementos, aliás, também sustentaram as ações para transformação postal no contexto internacional.

Com isso, o governo FHC elaborou um novo modelo organizacional para os Correios e de regulação para o setor postal brasileiro. Para isso, o Ministério das Comunicações desenvolveu um projeto, implantado a partir de 1997, denominado Reforma Estrutural do Setor Postal Brasileiro (RESP). As propostas abarcavam as seguintes diretrizes:

1) Reforma Regulamentar do Setor Postal: definição de um novo modelo de exploração dos serviços postais no Brasil, envolvendo questões fundamentais como serviços universais, monopólio, controle da Empresa Brasileira de Correios e Telégrafos - ECT, órgão regulador, etc.;

2) Reforma comercial e organizacional da ECT: modernização da empresa, [...] preparando-a para atuar em um novo contexto regulamentar a ser implantado no setor;

3) Serviços Financeiros Postais: a utilização da infraestrutura de atendimento da ECT para que, em parceria com o Sistema Financeiro Nacional, sejam prestados serviços financeiros básicos à parcela da sociedade atualmente não atendida pela rede bancária, isto é, a população rural e a população urbana de baixa renda. (BRASIL, 1998, p. 9, grifo do autor)

Em 1998, o governo federal finalizou o Programa de Reforma Estrutural do Setor Postal Brasileiro (RESP), o qual elaborou projetos para a reforma regulamentar, comercial e organizacional da ECT e cujo principal produto foi convertido pelo presidente FHC no projeto de Lei Geral do Sistema Nacional de Correios (Projeto de Lei no. 1.491, de 12 de agosto de 1999). 
O projeto de lei que propunha o Sistema Nacional de Correios, que à época se tornou conhecido como nova Lei Postal, foi desenvolvido e organizado para transformar radicalmente o setor. Sua concepção e desenvolvimento tiveram como inspiração as orientações da União Postal Universal, do Banco Mundial e reformas realizadas no âmbito da OCDE, sobretudo de países situados na União Europeia. A inspiração ideológica neoliberal, portanto, orientou a concepção do projeto.

Nas palavras de Egydio Bianchi (1999b, p. 03), presidente da ECT à época, era preciso reformular os serviços postais porque

[...] reconheceu-se que o modelo estruturado na década de 70 dava sinais de fadiga, ameaçando padrões de qualidade duramente conquistados em decorrência de fatores adversos surgidos ao longo de quase dez anos: aumento do tráfego postal, investimentos inexpressivos, atraso tecnológico, congelamento do quadro de pessoal, ingerências políticas, etc. Ao mesmo tempo, o governo e a ECT passaram a ficar atentos às grandes transformações ocorridas no sistema postal no mundo, impulsionadas pelas novas tecnologias de comunicação e pela desregulação dos mercados.

O governo FHC esperava aprovar rapidamente as mudanças postais no Congresso Nacional, tanto que contava com a tramitação do projeto em regime de urgência. Entretanto, parlamentares da própria base aliada do governo resistiram à votação do projeto em convocação extraordinária. Durante a tramitação nas comissões foram apresentadas mais de noventa e nove emendas pela base aliada do governo e por partidos de oposição, principalmente pelo Partido dos Trabalhadores (PT). Todavia, o plano do governo era aprovar a nova Lei Postal tal como apresentada.

\section{O que propunha, afinal, a nova lei?}

O projeto de lei previa a criação do Sistema Nacional de Correios, que seria formado pelas empresas privadas que entrassem no mercado postal pelo correio estatal e pela agência reguladora a ser criada (Agência Nacional de Serviços de Correios), formando, assim, a infraestrutura postal do país. A nova lei propunha a liberalização do mercado postal. Com isso, evidentemente, o monopólio da ECT seria eliminado. 
Com isso, o correio estatal e as empresas privadas passariam a oferecer "serviços postais", conceito que abarcava modalidades de serviços postais (serviços tradicionais, isto é, envio de objetos postais), serviços parapostais (serviços financeiros prestados em agências) e os serviços de interesse social (atendimento em pontos carentes de serviços básicos).

Cabe destacar, dentre os serviços parapostais, a criação de um banco postal para atuar em parceria com as agências da Correios do Brasil S.A. A prestação de serviços financeiros por meio do banco postal incluiria serviços de poupança, conta corrente, transferência bancária, recebimento de contas etc., ou seja, serviços bancários básicos, oferecidos principalmente à população de baixa renda e de localidades distantes das metrópoles.

Dessa forma, o Sistema Nacional de Correios possibilitaria aos operadores postais prestar diversos serviços, desde que obtivessem autorização. A necessidade de autorização para a entrada de algum operador no mercado implica a admissão em um Regime de Exploração para prestação de serviço, sendo a concessão, permissão e autorização os principais instrumentos para isso.

E quais seriam os impactos diretos sobre a ECT? A ECT seria transformada em Correios do Brasil S.A. Deixaria de ser uma empresa pública para se transformar em uma empresa de economia mista e, a partir disso, teria autorização legal para criar subsidiárias, participar de outras empresas, negociar suas ações etc. O governo FHC, no entanto, alegava que não pretendia privatizar a ECT, isto é, as ações da Correios do Brasil S.A seriam majoritariamente da União. Isso, todavia, não impediria que a empresa fosse transformada em subsidiárias passíveis de venda.

Em relação ao monopólio, o projeto da nova Lei Postal previa a atuação exclusiva da Correios do Brasil S.A em alguns segmentos - como a exploração de cartas, telegramas, cartões postais e malotes - pelo prazo máximo de dez anos, podendo ser reduzido para cinco. Ao final desse período, a liberalização do mercado seria total. Buscou-se, assim, uma quebra gradual do monopólio, tal como realizado nos países da União Europeia.

Para atuar em um mercado aberto à competição, a Agência Nacional de Serviços de Correios seria criada com os objetivos de regular, controlar 
e fiscalizar o Sistema Nacional de Correios. Caberia ainda à agência reguladora garantir a realização dos serviços postais essenciais, a manutenção da competição e a defesa dos interesses dos consumidores. A criação de uma agência reguladora independente, assim, retiraria do governo o poder de regulação do setor, transferindo-o a um órgão supostamente independente capaz de arbitrar sobre o mercado postal.

No entanto, como a nova Lei Postal foi recebida pelos empresários interessados no setor?

\section{ESTRATÉGIAS CORPORATIVAS DISSONANTES: O PAPEL DOS EMPRESÁRIOS NA DERROTA DA NOVA LEI POSTAL}

De acordo com o então ministro das Comunicações, Pimenta da Veiga, o projeto da nova Lei Postal "[...] chega com força ao legislativo (e) marcado pela legitimidade", já que teria sido submetido à sociedade e debatido por vários setores, propiciando o entendimento necessário à aprovação do projeto de lei. Assim, as resistências seriam menores no Congresso Nacional. (A SEGUNDA..., 1999)

Apesar do otimismo do ministro, o presidente da ECT, Egydio Bianchi, escreveu sobre a existência de "mal-entendidos" no projeto antes mesmo dele ser enviado ao Congresso. De acordo com o presidente da ECT, o primeiro "mal-entendido" versava sobre a privatização da ECT. Segundo ele (BIANCHI, 1999a, p. 03), "ao contrário do que se alardeia", "não está prevista a privatização dos Correios", embora "preparam-se para uma profunda reformulação, capacitando-se para disputar novos mercados, adotando parcerias e abrindo oportunidades para a ação empresarial privada".

De acordo com o projeto, a princípio a ECT não seria privatizada, mas transformada em Correios do Brasil S.A e assumiria integralmente a lógica empresarial para atuar em um mercado aberto. Assim, buscaria maximizar suas operações lucrativas ao mesmo tempo em que teria uma frente social, voltada para o atendimento de serviços financeiros para a população de baixa renda ou de localidades distantes. Esse modelo, nas palavras de Egydio Bianchi (1999b, p. 03), "é o modelo do banco postal, adotado com sucesso na Europa e na Ásia”. Em outras palavras, o governo 
FHC tentava, com o discurso de atendimento da população de baixa renda, legitimar a proposta.

Além disso, os "mal-entendidos", como disse o presidente da ECT, continuaram. Inclusive por parte de empresários do setor postal, que em tese deveriam estar comprometidos com o projeto. Nesse sentido, o presidente da então DHL afirmou à Folha de São Paulo estar em campanha junto aos seus clientes contra o projeto da nova Lei Postal porque ela garantiria o monopólio, que estaria sendo ampliado inclusive por meio da rede de atendimento. (CONTRA..., 1999) Dessa forma, empresários do setor começaram a alegar que o projeto de lei não eliminava o monopólio postal, pois ele permaneceria com a Correios do Brasil S.A por mais dez anos.

O protesto do presidente da $D H L$ explicita o paradoxo das estratégias das multinacionais: enquanto na União Europeia ainda estava em discussão o modelo de abertura e regulação de mercado, exigia-se a liberalização do setor postal brasileiro imediatamente. As estratégias econômico-corporativas e governamentais eram, portanto, dissonantes.

$\mathrm{Na}$ análise do Sindicato Nacional das Empresas de Encomenda (SINEEX), o projeto de lei ampliava o monopólio ao exigir que as empresas se submetessem ao órgão regulador. Nas palavras do então tesoureiro do SINEEX à Folha de São Paulo - em reportagem intitulada Oposição e Empresas criticam Lei Postal -, tratava-se de "um retrocesso o Estado intervir em um setor já ocupado pela iniciativa privada”. Para a SINEEX, a garantia do monopólio - mesmo em apenas um segmento do mercado - tornava o projeto inconstitucional, bem como as possíveis ingerências do Estado na iniciativa privada por meio de um órgão regulador. A entidade sugeria, ainda, que contas, boletos e cobranças fossem retirados da definição de "cartas" sob monopólio. (BAYMA, 1999)

No mesmo sentido, o Comitê das Empresas de Encomendas Expressas manifestou-se "contra abusos claros, ausências de regras explícitas e indispensáveis à regulamentação e à prestação dos serviços ao consumidor" (BAYMA, 1999, p. 27), o que abarcava a ausência de um detalhamento das atividades de um banco postal, bem como aspectos como a extinção e concessão de regimes de exploração. Além disso, aspectos como o poder de regulação da agência a ser criada foram muito criticados. Alegando 
representar um setor com mais de um milhão de trabalhadores, o Comitê afirmou estar preocupado com os rumos da competição privilegiada da Correios do Brasil S.A e as possíveis consequências para os trabalhadores. Em um contrassenso, o Comitê também afirmara estar "preocupado" com a estabilidade e o emprego dos funcionários da ECT.

Na mesma direção, de acordo com Bayma (1999), a Associação Nacional dos Transportadores de Carga - que afirmava ter mais de 12 mil associados - alegava realizar atividades correlatas aos serviços postais, mas que não devia subordinar-se ao órgão regulador postal, mas à Agência Nacional de Transportes Aéreos. Com isso, passou a defender, inclusive, a completa desregulação do setor, bem como a garantia de retorno financeiro pela concessão. Segundo o posicionamento da Associação, seguindo argumentos de outros grupos empresariais, o projeto de lei reforçaria o poder da Correios do Brasil S.A.

Em meio à disputa, a definição dos objetos postais submetidos ao monopólio pela Correios do Brasil S.A foi um dos elementos que mais criou atritos entre o governo e empresários. A reserva de mercado para "malotes" ou "correspondência agrupada" poderia ampliar, no entendimento de grupos empresariais, o poder da empresa estatal. (PAVONI JUNIOR; VASQUES, 2001) Com isso, entidades envolvidas com o comércio eletrônico sentiram-se ameaçadas com o impacto do projeto de lei aos seus negócios e também manifestaram sua desaprovação.

Assim, a Câmara Brasileira de Comércio Eletrônico associou-se às entidades empresariais, como a Confederação Nacional da Indústria (CNI), a Confederação Nacional dos Transportes (CNT), Federação do Comércio de Bens, Serviços e Turismo (FECOMERCIO), a Federação das Indústrias do Estado de São Paulo (FINDES), a Associação Brasileira das Empresas de Transporte Internacional Expresso de Cargas (ABRAEC) e a Câmara Americana de Comércio, para pressionar os parlamentares contra a nova Lei Postal "monopolista", que dificultaria, segundo as associações empresariais, as exportações, o comércio eletrônico e geraria insegurança jurídica sobre as atividades postais em decorrência da ambiguidade da definição de "carta". De acordo com o então secretário de serviços postais, a oposição de grupos empresariais ocorreu porque "as pessoas não tiveram 
tempo ou vontade de ler a lei inteira". A despeito disso, o Comitê das Empresas de Encomendas Expressas afirmava que "eles (os integrantes do governo) querem engordar a empresa para a privatização." (PAVONI JUNIOR; VASQUES, 2001)

As divergências com o projeto da nova Lei Postal, portanto, estavam centradas em um suposto excesso de regulação de mercado, na indefinição da área de atuação das agências da nova empresa de Correios como prestadora de serviços financeiros e, principalmente, na delimitação do segmento de mercado reservado por mais dez anos.

Sobre as posições dos atores que ora alegavam o interesse do governo FHC na privatização, ora a busca por reforçar o monopólio da empresa estatal, o então presidente da ECT tentou se explicar. Nas palavras de Egydio Bianchi (1999b, p. 03),

Para ter uma idéia da disparidade de opiniões, dizia-se, [...], que o governo estaria preparando a 'privatização' dos Correios. Como o anteprojeto da nova lei postal era ainda pouco conhecido, atribuímos tal afirmação à afoiteza, logo superada pelo conhecimento mais detalhado da proposta. Recentemente, alguns setores passaram a cometer outro tipo de engano: o governo estaria tentando 'ampliar o monopólio' dos Correios. Como se vê, entre um e outro equívoco há um enorme paradoxo.

Desde o início temos deixado bem claro que os princípios da grande reforma do sistema postal estão baseados na extinção do monopólio, na regularização do setor, no estímulo à competição, na preparação dos Correios para as disputas do mercado e na preservação dos serviços postais. E isso tudo não é propriamente sinônimo de privatização do sistema, muito aquém de ampliação do monopólio postal.

De acordo com Bianchi (1999a), a maior parte dos atritos decorria de dois elementos presentes no projeto de lei: o entendimento sobre exclusividade e essencialidade dos serviços e a necessidade de autorização para a livre iniciativa atuar no mercado postal. O então presidente da ECT explicou que serviços essenciais eram os serviços mínimos que o governo iria garantir à sociedade, abarcando objetos postais sem urgência e com até dois quilos. Isso buscava, segundo ele, resguardar a população em caso de operadores privados não atenderem adequadamente o segmento. 
Os serviços exclusivos, por sua vez, referiam-se aos segmentos de mercado que permaneceriam sob monopólio por no máximo mais dez anos após a aprovação da lei, o que incluía as cartas, telegramas, cartão postal e malotes (ou correspondência agrupada). Segundo Egydio Bianchi, eram os mesmos serviços cujo monopólio estava previsto pela legislação vigente. A diferença estava na introdução de um prazo para a liberalização. Sobre a necessidade de autorização e submissão a um regime de exploração, a explicação do presidente da ECT vinculou a proposta do governo ao aumento da competitividade no mercado, favorecendo a população. A regulação, assim, seria para normatizar a forma como os serviços poderiam ser mais bem realizados.

Para o então presidente da DHL no Brasil, Michael Canon (1999), apesar de o presidente da ECT citar "princípios louváveis" na defesa do projeto de lei - extinção do monopólio, estímulo à competição, regularização do setor etc. -, eles não se sustentavam nos artigos do projeto. Segundo ele, "[...] o que transparece é a nostalgia da era dos privilégios das estatais, um passo na contramão em tempos de abertura de mercado e de privatização de serviços públicos", e ainda afirma que o governo optara pela manutenção do monopólio, "[...] ainda que isso signifique caminhar na contramão de outros setores.” (CANON, 1999, p. 03)

Diante desses elementos, verifica-se que os principais grupos de oposição ao projeto estavam entre os empresários vinculados às entregas de encomendas expressas, incluindo os que atuavam na entrega de contas de luz e telefone, boletos bancários etc. Isso porque o conceito de carta que conferia o monopólio aos Correios foi questionado e houve a tentativa de retirar da abrangência do monopólio tais boletos de cobrança. Os transportadores de cargas, por sua vez, argumentavam que o conceito de encomenda expressa era muito abrangente, diminuindo o mercado para suas atividades.

Dentre os que questionaram o projeto, havia também a Associação Nacional de Jornais, que argumentava a favor do que entendia ser a "liberdade de imprensa”, isto é, a autonomia das empresas de comunicação na distribuição de jornais e revistas. A lei previa que toda empresa era livre para distribuir sua própria correspondência, mas não para distribuir produtos de terceiros. Para isso, era preciso autorização e pagar algumas 
taxas à agência reguladora. (NASSIF, 1999) Sendo assim, os empresários da comunicação usaram o mote da "liberdade de imprensa" a favor de seus interesses comerciais.

A oposição ao projeto entre empresários brasileiros e grupos internacionais em atuação no mercado nacional, portanto, foi grande e intensa. Em razão disso, audiências públicas foram realizadas na Câmara dos Deputados para discutir a nova Lei Postal, sendo algumas solicitadas por grupos e associações empresariais.

Contudo, não foram apenas os empresários que se opuseram às mudanças. Os trabalhadores dos Correios também se posicionaram contra o projeto da nova Lei Postal. Nesse sentido, em setembro de 2000, a Folha de São Paulo informava que os trabalhadores dos Correios iniciaram uma greve que, além de reivindicar reposição salarial e o aumento do auxílio refeição, demandava também "a retirada do projeto de lei que abre o mercado [postal] a empresas privadas." (SERVIDORES..., 2000)

As manifestações dos trabalhadores durante o governo FHC, assim, não se restringiram às reivindicações por reposição salarial, melhores condições de trabalho e aumento de benefícios, como nas greves ocorridas em 1994, 1995 - quando a reformulação do plano de cargos e salários também estava na demanda - e 1997, mas também pleiteavam a retirada do projeto de lei que transformaria o sistema postal brasileiro.

Com a oposição dos empresários do setor e as mobilizações dos trabalhadores, compreende-se a derrota do governo FHC na implantação do Sistema Nacional de Correios. Contudo, apesar das manifestações dos trabalhadores, foram as dissidências entre os grupos empresariais que selaram os rumos do setor à época.

O governo previa uma tramitação rápida do projeto de lei no Congresso Nacional, não prevendo a divergência e resistência dos grupos empresariais. Não obstante, o governo FHC pretendia a aprovação da Lei Postal na íntegra, sendo todas as emendas e substitutivos rejeitados. Isso explica porque o projeto, apresentado em 1999 na Câmara dos Deputados, ainda não havia sido votado em 2001 - véspera das eleições.

Ao perder força política no Congresso e legitimidade junto aos grupos empresariais, o projeto estendeu-se por várias comissões até a eleição do 
presidente Luís Inácio Lula da Silva em 2002, que solicitou no ano seguinte a retirada do projeto da nova Lei Postal.

A chegada ao poder do presidente Luís Inácio da Silva, no entanto, não suprimiu os projetos de reforma no sistema postal brasileiro. Como analisado a seguir, esse governo e o da presidente Dilma Rousseff reestruturaram a ECT, com continuidades e rupturas com o projeto de FHC.

\section{A REESTRUTURAÇÃO ORGANIZACIONAL DOS CORREIOS DURANTE OS GOVERNOS LULA E DILMA ROUSSEFF: APROFUNDAMENTO DA CORPORATIZAÇÃO}

O ministro das Comunicações do governo Lula, Hélio Costa, solicitou ao presidente da República em 2008 que formasse um grupo de trabalho para analisar o setor postal brasileiro e propor medidas para a sua modernização. Diante disso, o presidente Lula criou o Grupo de Trabalho Interministerial (GTI) no segundo semestre de 2008 com a finalidade de elaborar estudos e propor diretrizes para a modernização da ECT. As atividades iniciaram-se formalmente em fevereiro de 2009. O GTI foi composto por representantes do Ministério das Comunicações, da Casa Civil da Presidência da República, do Ministério do Planejamento, Orçamento e Gestão, do Ministério da Fazenda e da própria ECT.

A solicitação do ministro das Comunicações para criação do GTI foi justificada pelo contexto em que a ECT vinha atuando. Tal contexto dizia respeito à própria estrutura organizacional e de mercado da ECT e aos rumos do setor postal mundial. De acordo com o relatório final do GTI (BRASIL, 2009), o mercado postal, até a década de 1990, pode ser considerado estável. No entanto, desde então o processo de globalização, as novas tecnologias de informação e comunicação, além da intensificação do comércio internacional, têm impactado o mercado postal. Esses elementos, de acordo com os integrantes do GTI, criaram um novo ambiente de atuação para a ECT.

Diante disso, verifica-se que as motivações para formulação de planos visando mudanças na ECT, tanto no governo do presidente Fernando Henrique quanto no governo do presidente Luís Inácio, são basicamente 
as mesmas, isto é, aumento da competição, transformações tecnológicas, mercado globalizado etc. Contudo, há uma diferença central entre esses dois momentos da história da ECT: enquanto no governo FHC previa-se a abertura do mercado postal, o governo Lula justifica as mudanças na estatal como forma de fortalecê-la para atuar em um mercado mais acirrado.

Além disso, a intensa transformação no mercado postal em todo o mundo, com processos de privatização, fusões, formação de oligopólios para atuação em âmbito internacional, tem pressionado o mercado brasileiro, inclusive com a aquisição de empresas brasileiras de médio porte que atuam em segmentos específicos - os mercados mais rentáveis de encomendas em grandes centros urbanos. Essas empresas, que atuam sem uma regulação postal específica para o setor, representariam uma ameaça de mercado à ECT.

Somado a isso, haveria também aspectos internos à ECT restritivos à sua atuação de forma mais eficiente. Tais aspectos relacionavam-se à gestão da estatal e seu modelo empresarial. Isso porque a estatal previa o acirramento da competição no setor e a consequente necessidade de investimentos para manutenção da competitividade, o que demandaria, principalmente, flexibilidade corporativa para acionar estratégias gerenciais consideradas mais adequadas para manutenção do domínio de mercado. Em outras palavras, o Grupo de Trabalho propôs a necessidade de se aprofundar a corporatização da ECT.

Os trabalhos do GTI foram divididos em serviços prestados, infraestrutura e gestão. Segundo o GTI (BRASIL, 2009, p. 17), as restrições estruturais da ECT resumiam-se aos seguintes pontos:

a) Âmbito de atuação restrito, impedindo a atuação da empresa nos mercados internacionais;

b) Limitação do objeto social, o que dificulta a atuação da empresa em novos segmentos correlatos e afins, bem como inibe a atualização dos serviços, em especial na adoção de novas tecnologias;

c) Limitação legal para contratação de serviços para a Rede Postal Noturna;

d) Modelo empresarial desatualizado, especialmente no que concerne à personalidade jurídica da ECT, que ainda se encontra indefinida; $\mathrm{e}$ 
e) Situação precária de governança corporativa, resultado de modelo institucional e organizacional superados.

Verifica-se, diante dos aspectos elencados, que a impossibilidade da ECT atuar diretamente em território estrangeiro - em decorrência do decreto de sua criação que delimitava o território nacional como âmbito de atuação - foi apontada como uma restrição de mercado a ser superada. Isso porque a ECT vinha se restringindo a realizar acordos com correios oficiais e, eventualmente, contratos com operadores privados. De acordo com o GTI (BRASIL, 2009, p. 17), isso fragilizou a atuação internacional da ECT, sendo a

origem dessa fragilidade [...] a histórica prioridade e exclusividade conferida às parcerias com correios oficiais, cuja reputação, [...] são, muitas das vezes, bem inferiores [...]. Muitos dos correios oficiais, especialmente nas nações em desenvolvimento, não têm condições de garantir níveis mínimos de prazos e condições de entrega.

Com essa leitura, o GTI e a ECT propuseram a ampliação do mercado de atuação da ECT, sobretudo pela internacionalização de sua atuação, seja por meio de parcerias com empresas privadas transnacionais ou mesmo pela provisão direta de serviços em territórios estrangeiros. Dentre outros aspectos, isso poderia melhorar a qualidade dos serviços dos clientes brasileiros, recuperar as receitas perdidas com os baixos serviços prestados pelos correios oficiais estrangeiros, ampliar a oferta de serviços etc. (BRASIL, 2009)

Além disso, a estratégia do governo federal fica evidente: expandir as atividades da ECT para a América Latina. Segundo a estatal, os serviços postais na região são deficientes, o que lhe garante uma vantagem no mercado postal regional, sobretudo ao prestar suporte às atividades empresariais originadas no Brasil. Mesmo com a ECT prestando consultorias para melhorar o desempenho operacional de correios oficiais, a qualidade dos serviços prestados por eles não tem sido suficiente para atender "aos negócios privados e o processo de crescente integração regional que o governo brasileiro incentiva de modo permanente". (BRASIL, 2009, p. 18)

O governo do presidente Luís Inácio justificou essa estratégia com a apresentação de dados sobre a rede de atendimento da ECT, que 
representava $37 \%$ de toda a rede de atendimento da região. Ao mesmo tempo, $80 \%$ do volume de correspondências e $82 \%$ da receita postal da região eram da ECT, bem como os melhores níveis de qualidade dos serviços ( $D+1$ no Brasil e ausência de critérios de qualidade na região). (BRASIL, 2009) Enquanto os países da América Latina buscam implantar um serviço de encomenda de qualidade, a ECT oferece uma ampla gama de serviços. Em outras palavras, a vantagem competitiva da estatal brasileira justificava a sua expansão para países da América Latina, cabendo, portanto, uma reforma legal para isso.

Os estudos do GTI também apontaram o "modelo empresarial desatualizado" da ECT como outro ponto a ser alterado e, para isso, foi proposta a reestruturação do modelo organizacional da estatal como forma de proporcionar à empresa maior segurança jurídica e rapidez às ações gerenciais.

O processo de corporatização da ECT na década de 1960 a transformou em uma empresa pública, mas não a definiu como uma companhia limitada ou sociedade anônima, o que na opinião do governo Lula dificultava a adoção de mecanismos eficientes de governança. Assim, os membros do governo recomendaram que a ECT fosse reestruturada como uma empresa pública sob a forma de sociedade anônima, com capital exclusivamente da União (podendo ser posteriormente pulverizado e compartilhado com estados e municípios). Com essa medida, "os institutos da imunidade tributária e do precatório estariam preservados para [...] garantia da universalização dos serviços, mantendo a natureza [...] de interesse social, e afastando a possível interpretação de exploração de atividade econômica" dos serviços postais. (BRASIL, 2009, p. 25)

A proposição do governo Lula pela transformação da ECT em empresa organizada sob a forma de sociedade anônima coaduna-se ao processo de corporatização. Todavia, se na década de 1960 a ECT foi pioneira nesse processo no cenário internacional, o aprofundamento do processo de corporatização - transformando a ECT em sociedade anônima - já havia sido iniciado no contexto internacional a partir da década de 1990, com o objetivo de privatizar os serviços postais.

A Federação Nacional dos Trabalhadores em Empresas de Correios e Telégrafos, no entanto, desde o início dos estudos para transformação 
dos Correios em uma empresa pública organizada como sociedade anônima, posicionou-se contra a medida por acreditar ser a proposta contrária aos "interesses da população" e dos trabalhadores. (EM DEFESA..., 2010) A entidade alegava que a transformação da empresa em sociedade anônima permitiria a derrubada da Orientação Jurisprudencial 247, que impede demissões imotivadas na empresa, ensejando a livre demissão dos trabalhadores e ainda o corte de benefícios, precarizando o trabalho.

Os integrantes do governo alegaram, no entanto, que a Constituição de 1988 prevê a responsabilidade da União em "manter o serviço postal". Além disso, o monopólio postal legitimado em 2009 pelo Supremo Tribunal Federal não permitiria a venda de ações da ECT a investidores privados, caso ela fosse transformada em sociedade anônima. Seria necessária uma emenda constitucional para isso. Essa foi uma das respostas às críticas recebidas pelo governo.

Além disso, reestruturar a estatal como sociedade anônima em vez de companhia limitada era adequado, considerou o GTI, por proporcionar mais flexibilidade para corresponder "[...] às demandas do mercado e maior geração de valor para o acionista”, isto é, a própria União. Além desse aspecto, seria possível uma alteração no Estatuto da ECT para modificar os mecanismos de governança, com alterações na composição, funcionamento e atribuições dos órgãos da empresa para incorporar novas instâncias de administração.

Apesar disso, na 34a Plenária Nacional da FENTECT, realizada em 2009, o projeto de reestruturação foi debatido pelos representantes sindicais, que consideraram "a transformação dos correios em uma empresa S/A, tanto de capital aberto como fechado, [...] altamente prejudiciais à categoria”. Com base nisso, a entidade aprovou o início de campanhas contra a reestruturação da empresa.

Assim, no período antecedente às eleições presidenciais de 2010, o então presidente da ECT, Carlos Henrique Custódio, afirmou ao jornal Valor Econômico, no dia 22 de julho de 2010, que a proposta para transformação dos Correios em sociedade anônima estava descartada porque "houve rejeição dos sindicalistas, que temiam perder a estabilidade dos 
funcionários". A FENTECT se regozijou por ter supostamente vencido. Contudo, tratava-se de uma estratégia do governo.

Passadas as eleições presidenciais de 2010, o governo eleito da presidente Dilma Rousseff retomou o projeto de reestruturação do modelo organizacional da ECT. Uma de suas primeiras ações foi editar a Medida Provisória $n^{\circ}$. 532, de 28 de abril de 2011, convertida posteriormente na Lei no. 12.490 de 2011, que incorporou debates e proposições do Grupo de Trabalho Interministerial.

Dessa forma, a redação da Lei 12.490 redefiniu o espaço de atuação da ECT, que agora pode atuar tanto em território nacional como internacional. Assim, foram atendidas as estratégias de internacionalização. No entanto, de acordo com a ECT, seus primeiros passos focam apenas a abertura de escritórios em países do MERCOSUL para análise dos mercados locais. Contudo, o primeiro escritório no exterior foi aberto em Miami, Estados Unidos, porque, segundo a empresa, $42 \%$ do tráfego internacional vêm desse país. (CORREIOS ..., 2013)

Com a reestruturação organizacional da ECT, garantiu-se à estatal a possibilidade de constituir subsidiárias, adquirir o controle ou participação acionária em empreendimentos empresariais, podendo até converter-se na controladora de uma holding. Com essa medida, é possível a ECT, por exemplo, criar empresas de transporte aéreo ou participar de projetos de seu interesse ou do governo federal - como o projeto do trem de alta velocidade entre a cidade de Campinas e Rio de Janeiro - que proporcionariam maior agilidade ao transporte de objetos postais e livraria a empresa de problemas como os gargalos relacionados à rede postal aérea noturna.

A presidente Dilma Rousseff, ao capitanear o processo de reestruturação organizacional da ECT, não deixou de incorporar o aspecto mais polêmico das medidas propostas pelo Grupo de Trabalho Interministerial: aprofundar a corporatização da empresa. Para isso, a Lei 12.490 de 2011 trouxe também a seguinte inovação: "Art. 21-A. Aplica-se subsidiariamente a este Decreto-Lei a Lei no 6.404, de 15 de dezembro de 1976" (BRASIL, 2011, grifo nosso).

A estratégia política do governo federal foi suprimir a expressão "sociedade anônima" do texto da lei, mas sem deixar de incorporar os princípios 
e instrumentos da Lei das Sociedades Anônimas (Lei 6.404, de 17 de dezembro de 1976). Assim, não houve a abertura de capital da empresa, que continua sendo integralmente da União, mas a adequação organizacional e administrativa aos princípios da corporatização.

Para a adequação da ECT às diretrizes das sociedades anônimas, a estrutura organizacional da estatal foi alterada, com o acréscimo de órgãos de natureza administrativa. Dessa maneira, se antes a administração da ECT estava a cargo de um presidente responsável pela diretoria, com a reestruturação organizacional passou a contar com um Conselho de Administração, uma Diretoria Executiva (formada pelo presidente e oito vice-presidentes) e um Conselho Fiscal, atendendo aos anseios por melhorias na governança corporativa.

Como órgão máximo de decisão, criou-se na ECT a Assembleia Geral para deliberação das questões mais relevantes, com publicação de ata com as decisões tomadas. O Conselho de Administração, responsável por orientar e definir as estratégias de negócios, objetivos corporativos e monitorar os resultados, inclui no processo decisório sete membros. Destes, quatro são indicados pelo ministro das Comunicações. Além disso, fazem parte do Conselho de Administração o presidente da ECT, um integrante indicado pelo ministro do Planejamento, Orçamento e Gestão e um representante dos trabalhadores escolhido em eleição nacional. ${ }^{11}$

Diante desses elementos, verifica-se que, enquanto o governo do presidente Fernando Henrique Cardoso propôs transformações radicais no setor postal brasileiro, sendo o projeto quase todo descartado, os governos seguintes - Lula e Dilma Rousseff - implementaram importantes reestruturações no modelo organizacional da estatal. O objetivo dos governos petistas foi incorporar estratégias de governança corporativa comuns a empresas privadas e de economia mista, a fim de aprofundar a corporatização da ECT e, com isso, esperavam aumentar a eficiência gerencial.

1 O presidente da ECT continuou a fazer parte do Conselho de Administração, mas não mais como presidente. O primeiro presidente do Conselho de Administração - que pode ser qualquer um dos indicados pelo Ministério das Comunicações - com a reestruturação foi o próprio ministro das Comunicações, Paulo Bernardo, o que evidencia o interesse do governo em acompanhar a "crise" pela qual passava a empresa no período. 
A FENTECT, que no início de 2010 não agiu publicamente contra as possibilidades de reestruturação da ECT - supostamente por acreditar que com a eleição da presidente Dilma Rousseff o projeto não seria retomado -, passou a lutar contra as mudanças previstas com a edição da MP 532/2011, incorporando às suas campanhas e ações a oposição às mudanças. Com a publicação de jornais, participação em audiências públicas no Congresso Nacional e incorporação do tema à pauta de reivindicações, os protestos culminariam na greve de vinte e oito dias em novembro de 2011, quando a Federação se apresentou como defensora do "monopólio postal e um Correios 100\% público, de qualidade e estatal”. Contudo, a reestruturação da estatal já era um fato.

Ao mesmo tempo em que a reestruturação organizacional da ECT foi planejada e executada entre 1994 e 2011, as estratégias em torno da liberalização e regulação do mercado postal mobilizaram os agentes envolvidos e interessados, como debatido a seguir.

\section{DA JUDICIALIZAÇÃO À ARENA POLÍTICA: ESTRATÉGIAS EMPRESARIAIS PARA LIBERALIZAÇÃO POSTAL (2003-2011)}

A vitória do presidente Luís Inácio Lula da Silva nas eleições de 2002 resultou na retirada do projeto da nova Lei Postal em 2003. Com isso, a ECT continuou a exercer suas atividades com base nas legislações anteriores, principalmente na Lei no. 6.538, de 1978. Dessa maneira, a estatal continuou a beneficiar-se do monopólio postal.

Até a Constituição Federal de 1988, a legislação era explícita ao garantir o monopólio postal à ECT. No entanto, a nova Constituição trouxe em seu artigo 21, inciso X, que era de competência da União "manter o serviço postal e o correio aéreo nacional", e no artigo 22, inciso XII, que "compete privativamente à União legislar sobre o serviço postal". Não há, portanto, uma referência explícita ao monopólio da ECT, o que gerou divergências na interpretação da lei. Para alguns, sobretudo para os representantes das empresas privadas, era de competência da União a manutenção dos serviços postais, entendendo isso como regulação de mercado, e não a atuação na prestação direta e exclusiva de serviços 
postais básicos. O entendimento, inclusive, foi aceito pelo governo do presidente Fernando Henrique Cardoso e esteve implícito na formulação do projeto da nova Lei Postal. Assim, durante os anos 1990 até mesmo o governo federal assumiu a coexistência com operadores privados e deixou de combatê-los explicitamente por entender que a Constituição não garantia o monopólio à ECT.

A discussão sobre o monopólio a partir de 1995 arrefeceu as disputas entre ECT e empresas privadas, até mesmo pela sinalização do governo FHC em mudanças no setor. As atividades de correios, mesmo as que estavam então sob monopólio, não deixaram de ser realizadas pelos operadores privados.

Com a apresentação do projeto da nova Lei Postal em 1999, operadores privados entraram em disputa com o governo federal, acusando-o de privilegiar a empresa estatal, como discutido anteriormente. Apesar do argumento não ser convincente - pois, como analisado, o monopólio seria apenas estendido por mais dez anos -, o embate e as estratégias governamentais e empresariais não convergiram. Com isso, o projeto de lei foi retirado pelo presidente Luís Inácio Lula da Silva em 2003 e os instrumentos legais continuaram a ser o Decreto-Lei de 1978 e a Constituição Federal, com todas as divergências interpretativas do início da década de 1990.

Os operadores postais privados, todavia, não arrefeceram com o arquivamento do projeto da nova Lei Postal e se organizaram para combater por vias judiciais o monopólio postal.

Nesse contexto, é interessante observar as percepções dos empresários do setor sobre o tema. O Jornal LogWeb, dedicado aos empresários da área de logística, realizou uma pesquisa em 2004 sobre a percepção empresarial acerca do monopólio postal. A pergunta feita foi: "Muitos empresários do setor alegam que há uma tentativa de monopólio dos Correios. Isto realmente existe?" (MONOPÓLIO..., 2004)

Segundo o representante da FEDEX e ABRAEC,

Tivemos [as empresas do setor] uma forte pressão nos últimos anos com a tentativa do monopólio do Correio através do Projeto de Lei 1491/99 que, dentre outros pontos, tentou monopolizar cartas e correspondências. A ABRAEC e outras entidades de classe promoveram reuniões e 
debates no Congresso Nacional, o que resultou no arquivamento desse projeto de lei. (MONOPÓLIO ..., 2004)

Pelos argumentos, compreende-se como as entidades de classe estiveram conscientes de suas ações políticas para barrar o projeto de lei ao mesmo tempo em que a ECT retomou, a partir de 2002, os esforços e represálias para tentar coibir a violação ao monopólio:

Tanto existe a tentativa de monopólio que há casos, como em Teresina, PI, de uma empresa de distribuição que teve suas portas lacradas e a proprietária foi processada. O Congresso Nacional, no lugar de permitir a perseguição de empresários bem-sucedidos e de visão, deveria se empenhar em oferecer condições para que estas empresas, verdadeiras indústrias de serviços humanos, pudessem gerar cada vez mais empregos. [AMORIM, da TM Serviços]. (MONOPÓLIO..., 2004)

Sem dúvida alguma, a pressão existe, não só em cima das empresas do setor, como também nas empresas que se utilizam dos serviços, as quais se intimidam com as ações dos Correios e, para não se envolverem em questões jurídicas, preferem rescindir os contratos de serviços com as empresas privadas e retornarem aos Correios, causando, com isso, grandes transtornos e prejuízos às nossas empresas, principalmente com relação a custos de rescisão de mão-de-obra. [CASTRO, da THC Express] (MONOPÓLIO..., 2004)

Os depoimentos mostram ainda que os argumentos jurídicos acionados no início da década de 1990 estavam presentes nos anos 2000 e fundamentavam as estratégias que poderiam ser acionadas contra o monopólio postal:

A tentativa de monopólio realmente existe. Todavia, o pleito da ECT não tem fundamento legal, uma vez que a Constituição de 1988 em momento algum se refere aos serviços postais como um monopólio estatal. Na verdade, a constituição brasileira, diferente do que querem os Correios, é calcada sobre a égide da livre iniciativa/livre concorrência. As atitudes tomadas pela ECT têm o único objetivo de coagir a concorrência da iniciativa privada. (SOUZA, da LOGISTECH)

A Constituição Federal de 1988 considera apenas quatro tipos de atividades como monopólio da União: exploração de petróleo, gás natural, minérios e minerais nucleares e seus derivados. Assim, o monopólio postal, 
previsto na antiga Lei 6538/78, que regulamenta as atividades postais, não foi recepcionado pela Lei Maior. Contudo, no intuito de restabelecer o monopólio postal, foi encaminhado, à Câmara dos Deputados, o Projeto de Lei 1491/99, o qual acabou sendo arquivado em meados de 2003, o que trouxe incomensuráveis benefícios à iniciativa privada e à população em geral. Apesar do arquivamento do referido Projeto, as empresas privadas ainda encontram-se em posição desfavorável em relação às facilidades obtidas pelos Correios, como, dentre outros exemplos, a preferência no embarque de suas cargas em aeronaves e a isenção de tributos para bens de até determinado valor, quando importados através dos Correios. (MICHAEL CANON, presidente da DHL Express).

[...] Outro expediente que causa espécie é a interpretação viciada de uma Lei ultrapassada e não muito clara com a principal intenção de deter o controle total sobre o mercado de entregas rápidas do país e uma parte significativa do mercado de transportadoras. (BARROS, da BSL - Boy Service)

(MONOPÓLIO..., 2004)

Com base nesses argumentos que advogavam a inconstitucionalidade do monopólio postal, a Associação Brasileira das Empresas de Distribuição (ABRAED) acionou ${ }^{12}$ em 2003 o Supremo Tribunal Federal (STF) para que este reconhecesse a atividade postal como de natureza econômica e, por isso, devendo ser prestada também pelas empresas privadas. Segundo a ABRAED, empresas que entregam contas de água e luz, malotes, revistas e periódicos não deveriam ser processadas por violar o monopólio. De acordo ainda com a associação, as empresas afiliadas à entidade geravam pelo menos 1,2 milhões de empregos, sendo mais de quinze mil empresas no setor e uma rentabilidade de aproximadamente sete bilhões de reais ao ano. (FREITAS, 2005)

A análise judicial se estendeu de 2003 a agosto de 2009, quando o STF proferiu sua decisão, que em uma votação apertada (seis votos a quatro) garantiu o monopólio aos Correios e a constitucionalidade da Lei nº. 6.538, de 1978. Pela decisão, os ministros reconheceram o monopólio da ECT às cartas, cartões postais e correspondência agrupada (malotes), enquanto as

12 Trata-se da Arguição de Descumprimento de Preceito Fundamental - ADPF no. 46/2003. 
encomendas e impressos (incluindo jornais e revistas) ficaram facultados à livre concorrência. Com essa decisão do Supremo, punições como detenções e multas passaram a ser aplicadas somente às empresas que violassem o monopólio dos objetos restritos à ECT. Na ocasião, o presidente do STF comentou que "o impasse veio para mostrar que a legislação está carecendo de atualização". Para os operadores privados, a decisão garantiu uma segurança jurídica para atuarem, pelo menos, nos segmentos abertos à competição.

O mercado postal brasileiro, em uma estimativa da ECT, movimenta aproximadamente 20 bilhões de reais ao ano. Destes, a metade está com os estimados dois mil e quinhentos operadores privados que atuam no setor nos grandes centros urbanos. Da receita total da ECT, 50\% têm advindo dos serviços monopolizados, o que evidencia a importância do mercado reservado para a estatal.

No entanto, a discussão sobre a abertura do mercado ainda não foi encerrada. Tramita na Câmara dos Deputados o Projeto de Lei no. 3677/2008, do deputado Régis de Oliveira, do Partido Social Cristão, que também tem como foco o monopólio postal. Se aprovado, o conceito de carta passaria a englobar apenas a comunicação social entre pessoas físicas, eliminando na prática o monopólio. Assim, mesmo que juridicamente o assunto esteja pacificado, a esfera política ainda continua a ser uma arena de embate das distintas estratégias dos grupos privados e da ECT e seus trabalhadores, que durante as greves ocorridas em 2007, 2008 e 2009 se posicionaram contra a quebra do monopólio postal.

\section{ESTRATÉGIAS DE MERCADO ENTRE 1994 E 2011}

O plano de modernização dos Correios traçado pelo governo Fernando Henrique Cardoso abarcava uma reforma comercial que incluía o "reposicionamento do serviço postal, de simples entregador de correspondência a um diversificado provedor de serviços", e também a "redução da dependência do serviço regular de entregas, com implantação de serviços não tradicionais, como correio híbrido, courier, serviços financeiros, mensageria e atendimento, dentre outros." (BRASIL, 1997, p. 24) 
Buscava-se alinhar as estratégias mercadológicas da ECT às inovações na cadeia de valor do mercado postal que também estavam em curso na União Europeia. Naquele continente, os operadores postais buscavam, desde o começo da década de 1990, diversificar os serviços para agregar valor aos tradicionais segmentos de mercado e incrementar a lucratividade por meio do atendimento das demandas, sobretudo, dos clientes corporativos. (DIJKGRAAF; VAN der ZEE, 2009)

As diretrizes que norteavam a reforma comercial nos Correios durante o governo FHC coadunavam-se às propostas de criação do Sistema Nacional de Correios e a consequente liberalização do mercado postal. Em um cenário competitivo, a estatal deveria atuar em segmentos diversificados para que tivesse sustentação econômica.

Com isso, o governo FHC vislumbrou na segmentação de mercado a oportunidade de ampliar os serviços prestados pela ECT, oferecendo variados serviços para atender às diversificadas expectativas dos usuários. (BRASIL, 1997) Nesse sentido, foram identificados e propostos cinco segmentos de mercado em que a ECT deveria atuar: 1) correio tradicional, que abrange cartas e impressos convencionais relacionados ao transporte de informações e que enfrenta a concorrência direta das tecnologias de informação, como internet, televisão etc.; 2) encomendas, incluindo o serviço de entrega de mercadorias e objetos que não são passíveis de substituição por tecnologias, que, ao contrário do correio tradicional, tem se beneficiado do comércio eletrônico e é o principal alvo das empresas privadas; 3 ) correio híbrido, uma modalidade de serviço que combina a utilização de tecnologias informáticas para envio de mensagens e a impressão próxima ao local de distribuição; 4) atendimento ou serviços de conveniência, transformando as agências em lojas para a venda de serviços de atendimento; e, por fim, 5) a prestação de serviços financeiros, com as agências prestando serviços bancários.

A segmentação de mercado foi implantada parcialmente até o final da década de 1990. Como corolário, o governo FHC realizou uma mudança na natureza operacional e tarifária dos serviços postais, relacionando a tarifação à ordem de prioridade e encaminhamento dos objetos postais. Com isso, três categorias distintas de serviços foram estabelecidas, 
relacionando preço e prioridade de entrega: Serviço Expresso (com alta prioridade de encaminhamento e rapidez na entrega em detrimento do preço); Serviço Normal (focado no equilíbrio entre preço e velocidade de encaminhamento); Serviço Econômico (com baixa prioridade de encaminhamento e preço mais baixo).

Para o governo FHC, a nova classificação permitiria aos usuários a escolha do serviço adequado às suas necessidades - mais rapidez no encaminhamento e entrega ou preço mais acessível - e maior homogeneização das cargas, facilitando a padronização dos métodos de gestão do processo operacional, inclusive com a automação.

Durante o governo Lula, o Grupo de Trabalho Interministerial (GTI) instituído em 2009 centrou sua análise nas disputas em torno do monopólio postal e na importância dele para custear a universalização. Ao mesmo tempo, o GTI reiterou a importância dos segmentos de mercado abertos à competição e sua importância como fonte de financiamento e rentabilidade. Trata-se de um mercado composto por encomendas expressas, serviços de logística, serviços financeiros e digitais que, pela análise do GTI, precisava ser cada vez mais conquistado em razão de sua lucratividade. Todavia, aspectos legais, operacionais e tecnológicos foram apontados como capazes de restringir a atuação da estatal. (BRASIL, 2009)

De acordo com o Grupo de Trabalho (2009, p. 17), havia uma "limitação do objeto social [da ECT], o que dificulta a atuação da empresa em novos segmentos correlatos e afins, bem como inibe a atualização dos serviços, em especial na adoção de novas tecnologias". A "limitação do objeto empresarial" refere-se aos segmentos de mercado em que a ECT não estava autorizada a atuar pela legislação postal.

Assim, apesar de atuar no mercado postal competitivo, não havia previsão legal respaldando estratégias direcionadas a esses segmentos, sobretudo em atividades como logística integrada, correio digital e serviços financeiros. A recomendação do GTI, diante disso, foi pela ampliação do escopo de atuação da estatal pelo governo Lula.

Em consequência, o governo da presidente Dilma Rousseff, ao reestruturar a ECT com a edição da Lei no. 12.490, de 16 de setembro de 2011, incorporou esses segmentos mercadológicas ao escopo da estatal: 
Art. $2^{\circ}$ III - [A ECT fica autorizada a] explorar os seguintes serviços postais:
a) logística integrada;
b) financeiros; e
c) eletrônicos.

Parágrafo único. A ECT poderá, obedecida a regulamentação do Ministério das Comunicações, firmar parcerias comerciais que agreguem valor à sua marca e proporcionem maior eficiência de sua infraestrutura, especialmente de sua rede de atendimento. (BRASIL, 2011, grifo nosso)

Ao ampliar as estratégias de mercado, legitimou-se a atuação da estatal em outros nichos de mercado, incluindo a possibilidade de estabelecer parcerias empresariais para utilização da infraestrutura, facilitando acordos para transporte de objetos postais e, principalmente, a utilização de agências como "lojas de conveniência" que oferecem diversos produtos e serviços de terceiros.

Serviços de logística integrada incluem a captação, preparação, transporte, entrega domiciliar e prestação de contas aos clientes de pedidos/ remessas realizadas. Trata-se, portanto, da atuação em uma área que envolve a venda de mercadorias e produtos, cabendo à ECT a responsabilidade logística.

Os serviços eletrônicos remontam à modernização comercial da ECT na década de 1990 durante o governo FHC e apresentados no Programa de Recuperação e Ampliação do Sistema de Telecomunicações e do Sistema Postal. Ainda naquela década, já se vislumbrava a incorporação de tecnologias eletrônicas ao setor postal, sobretudo por meio do Correio Híbrido ${ }^{13}$ de e outras modalidades de serviço, como o investimento em correio eletrônico. Assim, a adoção de serviços eletrônicos ${ }^{14}$ incorpora uma estratégia de mercado delineada pelo governo FHC.

\footnotetext{
13 Consiste em uma modalidade de serviço que integra a tecnologia eletrônica e a entrega física das correspondências. O cliente envia a mensagem para a plataforma da ECT, que a imprime em uma central de distribuição próxima ao endereço do destinatário.

14 Entre os serviços eletrônicos que a ECT pode prestar, por exemplo, estão a emissão de certificados digitais, a atuação na mensageria eletrônica - remessa digital de documentos com segurança e confiden-
} 
O governo do presidente Fernando Henrique pretendia obter respaldo legal para criar um banco postal com a aprovação da nova Lei Postal. Com a derrota do projeto de lei, o governo editou portaria autorizando a ECT a funcionar como prestador de serviços financeiros. Assim, a ECT obteve autorização do Conselho Monetário Nacional e do Ministério das Comunicações para funcionar como "correspondente bancário", já que não havia autorização legal para constituição de um banco postal próprio. Assim, incorporaram-se às atividades da ECT serviços financeiros, abarcando desde vales-postais, recebimento de contas, vendas de títulos de capitalização, pagamentos de tributos, etc., a operações financeiras básicas.

As operações do Banco Postal como prestador de serviços financeiros representaram, em 2010, apenas 2,7\% do faturamento da ECT - R \$322,00 milhões. Criado em 2002 e funcionando em parceira com o Banco Bradesco até 2010, tem se direcionado, sobretudo, à população de baixa renda. Até 2010, foram mais de dez milhões de contas abertas em 95\% dos municípios brasileiros, o que mostra a importância do serviço, principalmente, nas localidades onde não há agências bancárias. (ECT, 2010) Em 2011, em uma negociação bilionária, o Banco do Brasil disputou com o Bradesco e venceu a licitação para incorporar o serviço prestado pela ECT.

Com a proposta do GTI durante o governo Lula e a autorização legal obtida durante o governo Dilma Rousseff, a prestação de serviços financeiros foi, finalmente, incorporada ao Estatuto Social da empresa. Com isso, em novembro de 2013 o Banco do Brasil e a ECT anunciaram que pretendem criar em sociedade igualitária um Banco Postal.

Em 2010, o tráfego postal da ECT atingiu 8,9 bilhões de objetos distribuídos. Com isso, a receita de vendas da empresa alcançou $\mathrm{R} \$ 12.690$ bilhões. Desse montante, 7\% foram de lucro líquido, isto é, R\$ 827,00 milhões. (ECT, 2010)

Os negócios da ECT, até a reestruturação comercial em 2011, eram compostos por serviços de mensagens, serviços de marketing, encomenda, malote, conveniência, logística, remessas internacionais e serviços financeiros.

cialidade e comprovação de autenticidade, serviço já utilizado por alguns tribunais -, e-mail, shoppings virtuais e o próprio correio híbrido. 
Os serviços de mensagens - carta social, comercial e não comercial e FAC (Franqueamento Autorizado de Cartas) -, voltados à comunicação da sociedade e empresarial, responderam por $47,50 \%$ da receita de vendas. Os serviços de encomendas - encomenda expressa via SEDEX e encomenda econômica pelo PAC - corresponderam a 29\% da receita do exercício. Na sequência, os serviços de marketing direto (para envio de impressos e mala postal direta), com 8,7\%, e demais serviços integram o portfólio que garante saldos positivos à empresa.

Com esses dados, evidencia-se a importância dos serviços monopolizados para a ECT, garantindo quase a metade da receita de vendas da estatal, apesar do crescimento percentual dos segmentos de mercado abertos à competição.

\section{A "CRISE DOS CORREIOS": RELAÇÕES ENTRE POLÍTICA E GESTÃO}

A nomeação de quadros políticos para a administração da ECT tem sido constante na história da estatal, já que a empresa é um órgão da administração pública federal. Desde 1994, no entanto, a presença de agentes políticos na condução da estatal tem exposto problemas gerenciais que decorrem, em alguns momentos, de estratégias políticas.

Nesse sentido, durante o governo do presidente Fernando Henrique Cardoso já se observava querelas sobre a nomeação de quadros políticos para cargos de gestão e como isso influenciava o desempenho da organização.

Assim, por exemplo, o Ministro das Comunicações do primeiro mandato do governo Fernando Henrique, Sérgio Motta, foi questionado pela revista Veja sobre a situação na ECT:

Veja: Mas por que o seu ministério não fez nada nos Correios até agora [julho de 1997]?

Sérgio Motta: Só não melhorou até agora porque, de todos os órgãos do ministério, o único que não pude controlar desde o início foram os Correios. O presidente foi nomeado pelo PPB [atual Partido Progressista] e... Você sabe o nome do presidente dos Correios?

Veja: Não 
Sérgio Motta: Pois é, ninguém sabe nem o nome do sujeito. Mas estou com carta branca para mexer nisso também. (PETRY, 1997, p. 12)

Diante da fala do ex-ministro, constata-se que até 1997 os Correios estavam fora do controle político do grupo majoritário do governo federal e comandado por correligionários políticos, em uma evidente lógica fisiologista.

Ao assumir o controle dos Correios em 1998, Sérgio Motta nomeou Egydio Bianchi para a presidência da ECT visando à reestruturação da estatal. Com a morte de Sérgio Motta, FHC nomeou Pimenta da Veiga para a pasta. Durante o período de negociação da nova Lei Postal, embates públicos foram travados entre o presidente da ECT e o novo Ministro das Comunicações, culminando com a demissão de Bianchi em julho de 2000.

Segundo o ex-ministro Pimenta da Veiga, a demissão de Bianchi ocorreu por "incompatibilidade de métodos administrativos, que dificultava o trabalho em equipe". Com isso, o ministro afirmou estar combatendo a autonomia excessiva de Bianchi e a sua autopromoção por meio dos canais de comunicação dos Correios. (PIMENTA..., 2000)

Bianchi, por sua vez, acusou o ministro de ceder ao lobby de empresas de encomendas expressas e de transportes e patrocinar alterações no projeto da nova Lei Postal para favorecê-las, o que levaria à demissão de metade, como disse Bianchi, dos funcionários da ECT e causaria enorme prejuízo. Além disso, também o acusou de tentar controlar a verba publicitária dos Correios para beneficiar grupos aliados. (PIMENTA..., 2000)

Além da troca pública de insultos por meio da imprensa, Bianchi acusou o ministro de pressioná-lo para aceitar um contrato com a VASP para transporte aéreo elaborado com base em documentos falsos; o acusou ainda de receber automóveis comprados em licitação de ano anterior ao licitado (veículos de 1998 como se fossem de 1999); de recorrer a amigos corretores para transacionar os imóveis da ECT e obter vantagens pessoais com isso; ceder a lobistas, etc. A resposta do ministro Pimenta da Veiga, por meio do assessor de imprensa do Ministério das Comunicações, foi que "Histórias contadas por aquele louco demitido [Bianchi] e por aquela japonesa [Wilma Motta, esposa do falecido ministro Sérgio Motta], não vão ser comentadas por ninguém do ministério." (PINHEIRO, 2000) 
Com a demissão de Bianchi, Pimenta da Veiga nomeou Hassan Gebrim, correligionário de sua confiança, para comandar os Correios.

Os embates enfraqueceram as mudanças propostas pelo projeto da nova Lei Postal. Com isso, verifica-se que no governo FHC as disputas entre grupos da própria base governista influenciaram as estratégias para o setor postal, com impacto também sobre o desempenho operacional da empresa. ${ }^{15}$

No governo do presidente Lula, mais precisamente em 2005, a ECT foi o epicentro de uma crise no governo federal, tornando-se foco de inúmeras reportagens na mídia brasileira em decorrência de escândalos políticos envolvendo supostos casos de desvio de dinheiro por agentes políticos e funcionários da estatal.

Em meados de 2009, a ECT passou a ser foco de reportagens sobre a deterioração da qualidade dos serviços operacionais. Esses elementos passaram a ser tratados pela mídia como "a crise da ECT."16 São dois aspectos entrelaçados, portanto, que envolvem a "crise": aspectos políticos e gerenciais.

A ascensão do Partido dos Trabalhadores ao poder em 2002 resultou em acomodações de correligionários em cargos de confiança e gerenciais nos órgãos estatais, evidentemente, sobretudo por ter chegado ao poder em uma coalizão partidária. Com isso, entre 2003 e 2010, o comando do Ministério das Comunicações ficou a cargo do Partido da Social Democracia Brasileira (PMDB). A escolha dos dirigentes dos órgãos vinculados ao ministério, assim, foi influenciada pelas orientações do mandatário do ministério. Entretanto, além do PMDB, o Partido Trabalhista Brasileiro (PTB) também indicava correligionários para cargos de confiança nos Correios.

No caso específico dos Correios, no entanto, o Estatuto Social da estatal previa que somente o presidente, vice-presidentes e diretores fossem nomeados em cargos comissionados. Os demais funcionários teriam que

\footnotetext{
15 À época, problemas nas licitações das agências franqueadas também entraram na disputa política.

16 A visibilidade dos problemas operacionais da ECT precisa ser analisada também a partir do alinhamento ideológico dos grupos midiáticos, que deram visibilidade a problemas antigos na empresa a partir de 2002 como forma de se posicionar politicamente durante o governo Lula. Destaco isso a partir dos indícios observados nos acervos dos principais jornais consultados: há escasso material tratando dos problemas da ECT durante a década de 1990 e inumeráveis reportagens sobre os problemas operacionais na década seguinte.
} 
ser do próprio quadro da estatal. ${ }^{17}$ Portanto, as agremiações políticas nomeavam os quadros estratégicos da empresa, a alta direção, mas tinham que alocar aliados internos dentre os funcionários da estatal.

As acomodações de aliados políticos em cargos gerenciais são discricionárias, não havendo, assim, ilegalidade no ato administrativo em si. No entanto, em 2005, o nome da ECT esteve no epicentro de um suposto esquema de cobrança de propina que originou a Comissão Parlamentar Mista de Inquérito (CPMI) "dos Correios". O funcionário dos Correios e diretor do Departamento de Contratação e Administração de Material, Maurício Marinho - apadrinhado do deputado federal Roberto Jefferson (PTB-RJ) - foi flagrado cobrando propina de empresários interessados em negócios fraudulentos. ${ }^{18}$

Com o escândalo, toda a direção da ECT solicitou demissão, a pedido do presidente da República. Interinamente, Janio Cezar Luiz Pohren, ${ }^{19}$ funcionário de carreira, foi nomeado como novo diretor, permanecendo no cargo até julho de 2006.

Com a crise institucional, o PMDB saiu fortalecido. Ainda em julho de 2005, Hélio Costa (PMDB) foi nomeado ministro das Comunicações, permanecendo no cargo até março de 2010. Em julho de 2006, Carlos Henrique Custódio foi nomeado presidente da ECT, ficando no cargo até julho de 2010.

Na gestão de Hélio Costa no Ministério das Comunicações iniciaram-se os estudos do Grupo de Trabalho Interministerial que culminaram na reestruturação organizacional da ECT em 2011, já no governo da presidente Dilma Rousseff.

17 O novo Estatuto dos Correios, aprovado em 2011 na esteira da reestruturação organizacional da empresa, permite que servidores de outros órgãos sejam remanejados para a ECT conforme a conveniência dos diretores da empresa.

18 O escândalo resultou na CPMI e na Ação Penal 470, julgada pelo Supremo Tribunal Federal. Para os propósitos deste livro, o episódio interessa por revelar as agremiaçōes políticas que comandavam a estatal.

19 Em sua gestão, Janio Cezar Luiz Pohrein destacou os problemas na Rede Postal Aérea Noturna e a dificuldade para encontrar empresas no mercado aéreo brasileiro interessadas na logística dos Correios, o que seria um problema para o desempenho das atividades operacionais. A criação de empresas de logística foi uma sugestão de consultorias contratadas pela ECT. A ideia, como analisado, foi incorporada às proposições do Grupo de Trabalho Interministerial que resultaram na reestruturação da ECT e na autorização para constituição de subsidiárias. 
Durante a gestão de Carlos Henrique Custódio na presidência da ECT, portanto, foram elaborados os projetos para reestruturação da empresa. Em sua gestão, a margem de lucros da estatal aumentou, assim como os resultados operacionais. Em uma reportagem de 2009, a revista Isto é Dinheiro o chama de "O entregador de resultados", atestando a sua capacidade administrativa. Segundo Custódio, a sua eficácia gerencial resultava da sua capacidade de "[...] dar mais valor ao Excel do que ao Word". (GANTOIS, 2009) Enfatizava, assim, a eficácia de suas ações pela possibilidade de aumentar a lucratividade.

Quando foi demitido em 2010, Custódio afirmou que a decisão era política, já que do ponto de vista operacional sua gestão tinha sido eficaz: "Posso discutir todos os números: faturamento, produtividade, salários e comparar com outros correios do mundo." (GOY, 2010)

De fato, a decisão de substituir Carlos Henrique Custódio era política: fora tomada diretamente em decorrência da crise operacional que assolava a ECT desde meados de 2009, quando problemas operacionais passaram a ser noticiados com recorrência pela mídia.

A deterioração da qualidade operacional da ECT a partir de 2009 é, aparentemente, contraditória ao se analisar os resultados financeiros obtidos no período. Contudo, é preciso reiterar que o sistema postal é dependente, em todo o mundo, da utilização intensiva de força de trabalho.

Apesar disso, em 2009, em mais uma de suas ações com o "Excel", Custódio iniciou um Plano de Demissão Voluntária (PDV) para reduzir a folha de pagamentos e as despesas com os funcionários. Mais uma ação administrativa, portanto, calcada na instrumentalidade gerencial.

Para aderir ao programa, os funcionários tinham que estar em atividade - caso fossem aposentados; ser funcionário dos Correios por pelo menos dez anos; e ter 50 anos de idade e mais de 30 anos de trabalho na ECT. O objetivo era, assim, demitir os funcionários com as maiores remunerações e, possivelmente, com maiores despesas em benefícios como plano de saúde.

A estatal declara no Relatório de Gestão de 2009 que 45.982 funcionários eram elegíveis à época. Destes, 5.912 aderiram ao programa. Segundo a empresa, os resultados foram a "redução da massa salarial, possibilitando 
ganhos que possam ser investidos em outras ações de gestão de pessoal" e a "diminuição do perfil etário, permitindo a oxigenação do quadro funcional". Por isso, a estatal afirmou: "Conclui-se que o Plano de Desligamento Voluntário - PDV 2009 foi bem sucedido, pois além de reduzir o custo da folha de pagamento em aproximadamente $7 \%$, conseguiu atingir os objetivos então propostos." (ECT, 2009, p. 33)

Apesar de a empresa ter considerado o plano bem sucedido por ter reduzido a folha de pagamentos, os custos operacionais foram altos. Além do conhecimento tácito dos funcionários que foram estimulados a solicitar o desligamento da empresa, o número de trabalhadores diminuiu consideravelmente, impactando a qualidade dos serviços prestados.

Ainda em 2009, a direção da estatal já planejava a realização de novo concurso (seleção externa). Contudo, a escolha da instituição promotora da seleção ocorreu sem licitação, o que motivou o Ministério Público Federal a solicitar o cancelamento do certame. ${ }^{20}$ (MPF, DF, RECOMENDA..., 2010)

Assim, o baixo número de funcionários, que se iniciou na metade de 2009, mantinha-se no final de 2010 e se somava à necessidade de novas contratações. Além disso, a falta de funcionários se somava a outros problemas operacionais. No início de 2010, a estatal não conseguiu renovar os contratos para transporte de carga na Rede Postal Aérea Noturna, o que resultou em atrasos no transporte da carga postal. Os atrasos resultaram em prejuízos, naquele momento, estimados em quase R 6 milhões. Concomitantemente, o fundo de previdência privada dos Correios (POSTALIS) apresentou prejuízo de R 1,43 bilhão - assumido pela estatal.

Diante disso, os diretores regionais da ECT posicionaram-se contra a crise em documento elaborado para ser encaminhado ao presidente Lula. No documento, ${ }^{21}$ os diretores afirmam que diante da crise operacional da empresa, um plano emergencial deveria ser acionado a partir de março de

20 O MPF alegou que a Fundação Cesgranrio foi contratada sem licitação. O nome da Fundação apareceu em uma lista, em 2005, de fornecedores da ECT em posse de Maurício Marinho, o que deixou a relação entre a Fundação e a ECT na berlinda. Assim, a própria ECT e a Controladoria Geral da União suspeitaram do favorecimento ilegal da instituição.

21 A manifestação dos diretores foi denominada "Posicionamento dos Diretores Regionais da Empresa Brasileira de Correios e Telégrafos ao Excelentíssimo Senhor Presidente da República Luís Inácio Lula da Silva sobre os Problemas que Envolvem a Qualidade dos Serviços Prestados à População". 
2010, incluindo "um conjunto de medidas e ações emergenciais visando à minimização dos impactos negativos na qualidade operacional da ECT, principalmente relativas à falta de pessoal e a regularização dos serviços de transporte aéreo".

Segundo os diretores,

A inclusão de ação relativa à contratação de empresa para a realização de concurso público foi considerada na referida reunião como imprescindível para a retomada da qualidade dos serviços prestados. Referida ação não teve a correspondente e necessária aprovação pela Diretoria da Empresa.

Apesar disso, os diretores regionais deram continuidade ao plano emergencial na ECT, embora a implementação das

[...] ações aprovadas, por si só, não conseguiram a reversão da situação da qualidade dos serviços da Empresa. Esta conclusão nos conduz à constatação, mais uma vez, de que realmente somente com a reposição e acréscimo de pessoal poderemos vislumbrar o resgate da qualidade dos serviços e da credibilidade da Empresa junto à população.

E concluem:

Em decorrência dessa constatação entendemos que a falta de decisão da Diretoria da Empresa naquela ocasião foi determinante para a manutenção dos críticos níveis de qualidade dos serviços prestados.

A carta dos diretores regionais, respaldada pelo diretor de operações Marco Antônio Oliveira, resultou - em um primeiro momento - na demissão deste em junho de 2010. Um mês depois, o presidente da estatal, Carlos Henrique Custódio, e o diretor de recursos humanos, Pedro Bifano, também foram demitidos. A decisão partiu da Casa Civil e do presidente Lula.

A "crise nos Correios" no governo Lula resultou, assim, de sucessivas ações administrativas que ocasionaram a deterioração da qualidade dos serviços operacionais. Nesse sentido, a crise se iniciou com ações para redução da força de trabalho, sobretudo na área operacional. A não realização de concursos mais o Programa de Demissão Voluntária resultaram na 
escassez de funcionários. Não por acaso, foi em 2010 que as denúncias de terceirização de atividades de carteiro e operadores de triagem e transbordo pela FENTECT aumentaram.

Além disso, o modelo organizacional da ECT e a necessidade de submeter-se à lei de licitações, associada à inépcia dos dirigentes da estatal incapazes de buscar alternativas gerenciais, conduziram à crise na rede de transporte aéreo. ${ }^{22}$

É importante reiterar, todavia, que subjacente à crise envolvendo aspectos gerenciais havia também estratégias políticas pelo comando dos Correios alimentando os embates, em especial a disputa entre PMDB e PT.

As demissões do presidente da ECT, Carlos Henrique Custódio, e do diretor de recursos humanos, Pedro Bifano, teriam sido uma intervenção direta do presidente da República, sob orientação da ministra da Casa Civil, Erenice Guerra, e do ministro do Planejamento, Paulo Bernardo, encarregados de diagnosticar os problemas na ECT e propor medidas para sanar a crise.

O novo presidente da ECT, David José de Matos, foi uma indicação da ministra Erenice Guerra. Pouco antes da eleição presidencial, foi amplamente noticiado um suposto esquema de lobby na Casa Civil envolvendo o filho da ministra. O presidente da ECT, por sua vez, foi vinculado a um suposto contrato superfaturado para favorecer uma empresa aérea que iria operar a Rede Postal Aérea Noturna.

Diante disso, a ministra Erenice pediu demissão do cargo em setembro de 2010 para não comprometer a campanha da candidata do PT à presidência, enquanto David José de Matos permaneceu no cargo até o início de janeiro de 2011.

Já no governo da presidente Dilma Rousseff, o novo ministro das Comunicações, Paulo Bernardo, que havia sido encarregado pelo ex-presidente Lula de sanar a crise nos Correios, indicou Wagner Pinheiro de Oliveira para a presidência da ECT. Com isso, o Partido dos Trabalhadores

\footnotetext{
22 A Comissão de Fiscalização e Controle da Câmara dos Deputados, por meio da Proposta de Fiscalização e Controle no. 113, de 2010, solicitou ao Tribunal de Contas da União auditoria na ECT para avaliar os atrasos nas correspondências e encomendas, concluindo que os principais problemas eram a falta de carteiros e operadores de triagem e transbordo e problemas na Rede Postal Aérea Noturna.
} 
assumiu o comando do Ministério das Comunicações e da ECT com o compromisso de soerguer a estatal.

Foi nesse momento que a reestruturação organizacional da ECT sob o governo Dilma Rousseff ocorreu. As medidas para aprofundar a corporatização dos Correios disponibilizaram, também, instrumentos gerenciais aos diretores da estatal. Nesse sentido, a possibilidade de criar empresas subsidiárias pode favorecer estratégias que visam solucionar problemas na Rede Postal Aérea, por exemplo, ou mesmo a participação em empreendimentos governamentais de interesse da companhia - como o trem de alta velocidade entre Campinas e Rio de Janeiro.

Além disso, uma das primeiras medidas do novo presidente da ECT foi a realização, em 2011, de uma seleção externa para contratação de cerca de dez mil novos trabalhadores e a promessa de novos concursos, principalmente para a área operacional.

Esses elementos mostram que os aspectos gerenciais na ECT estão imbricados com as estratégias políticas, mostrando que a capacidade de governança dos agentes públicos também é responsável pela eficácia gerencial.

\section{CONSIDERAÇÕES FINAIS}

Como apresentado neste capítulo, foram várias as transformações nos Correios entre 1994 e 2011. Durante o governo de Fernando Henrique Cardoso emergiram os principais pontos que integraram a pauta de discussões no setor postal nos anos seguintes. Dentre eles, a nova Lei Postal sintetizava o arranjo institucional proposto pelo governo FHC para o setor. A proposta previa a liberalização do mercado postal brasileiro com a eliminação gradual do monopólio da ECT e, em seu lugar, a criação do Sistema Nacional de Correios. A regulação do setor ficaria a cargo de uma agência reguladora responsável pela fiscalização e por garantir o cumprimento das normas que seriam estabelecidas.

O presidente Luís Inácio Lula da Silva descontinuou a tramitação do projeto da nova Lei Postal e manteve o monopólio para o segmento de cartas e mensagens, restringindo a competição aos nichos de mercado previstos na Lei no. 6.538, de 1978, o que não foi alterado pelo governo Dilma 
Rousseff. Ao mesmo tempo, a regulação do mercado continuou a ser exercida diretamente pelo governo. A ECT, assim, continuou a operar com a estrutura de mercado criada durante a ditadura militar.

Em relação à estrutura organizacional da estatal, verifica-se que o governo de Fernando Henrique propunha a transformação da ECT em uma sociedade de economia mista, com autonomia para constituir subsidiárias. Os governos Lula e Dilma Rousseff mantiveram a ECT como empresa pública com capital pertencente à União, mas incorporaram à estrutura organizacional da empresa instâncias de governança e administração adotadas por sociedades anônimas, além da possibilidade de a estatal constituir subsidiárias ou adquirir empresas já existentes.

No período analisado, as estratégias governamentais foram para incrementar a participação em diversos segmentos de mercado. Para isso, a reestruturação ocorrida no governo Dilma Rousseff institucionalizou a participação da empresa em segmentos de mercado não previstos na Lei no. 6.538, de 1978, adotando também as estratégias do governo FHC que previam a incorporação de tecnologias da informação aos segmentos de mercado e à rede de serviços. (TEIXEIRA, 2014) Nesse sentido, o banco postal já estava previsto pelo governo FHC, tendo funcionado com base em portaria publicada pelo ex-presidente como estratégia adotada para implementar o Banco Postal ante a derrota da nova Lei Postal. Com a reestruturação da ECT no governo Dilma, a ECT obteve autorização legal para constituir um banco próprio, além de atuar em outros segmentos de mercado indicados previamente pelo governo FHC. As estratégias de mercado, portanto, tiveram continuidade.

O quadro 4, a seguir, compara as propostas e as mudanças na ECT durante o período:

QUADRO 4 - PROPOSTAS E MUDANÇAS NA ECT DURANTE OS GOVERNOS FHC, LULA E DILMA ROUSSEFF

\begin{tabular}{|l|l|l|}
\hline & Governo FHC & Governos Lula/Dilma Rousseff \\
\hline Abertura de mercado & $\begin{array}{l}\text { Propôs abertura do mercado } \\
\text { postal com eliminação } \\
\text { gradual do monopólio. }\end{array}$ & $\begin{array}{l}\text { Manutenção das restrições de } \\
\text { mercado com defesa do monopólio. }\end{array}$ \\
\hline Estrutura de mercado & $\begin{array}{l}\text { Propôs criação do Sistema } \\
\text { Nacional de Correios. }\end{array}$ & $\begin{array}{l}\text { Não alteraram estrutura } \\
\text { do mercado postal. }\end{array}$ \\
\hline
\end{tabular}




\begin{tabular}{|c|c|c|}
\hline $\begin{array}{l}\text { Relação entre empresas } \\
\text { no mercado postal }\end{array}$ & $\begin{array}{l}\text { Competição entre operadores } \\
\text { públicos e privados no Sistema } \\
\text { Nacional de Correios. }\end{array}$ & $\begin{array}{l}\text { Competição somente nos segmentos } \\
\text { de mercado ausentes de monopólio. } \\
\text { Empresas ainda são proibidas de } \\
\text { atuar onde há reserva de mercado. }\end{array}$ \\
\hline Agência reguladora & $\begin{array}{l}\text { Propôs criação de } \\
\text { agência reguladora. }\end{array}$ & Regulação estatal. \\
\hline $\begin{array}{l}\text { Arranjo institucional e } \\
\text { organizacional da ECT }\end{array}$ & $\begin{array}{l}\text { Pretendia transformar a ECT em } \\
\text { sociedade de economia mista, } \\
\text { com criação de subsidiárias. }\end{array}$ & $\begin{array}{l}\text { Transformaram a ECT em empresa } \\
\text { pública com capital fechado e } \\
\text { integralmente da União, com } \\
\text { estrutura e diretrizes das sociedades } \\
\text { anônimas. Permitida constituição } \\
\text { ou aquisição de subsidiárias. }\end{array}$ \\
\hline Banco Postal & $\begin{array}{l}\text { Previa a criação de banco próprio, } \\
\text { mas só conseguiu autorização } \\
\text { para operar por meio de parceria. }\end{array}$ & $\begin{array}{l}\text { Aprovaram instrumento legal para } \\
\text { criação de banco postal próprio. }\end{array}$ \\
\hline Segmentos de mercado & $\begin{array}{l}\text { Previa a competição da empresa } \\
\text { em todos os segmentos } \\
\text { do mercado postal. }\end{array}$ & $\begin{array}{l}\text { Aprovaram lei para diversificar } \\
\text { atuação de mercado da ECT, como } \\
\text { em serviços de logística integrada. }\end{array}$ \\
\hline Foco de mercado & Mercado nacional. & $\begin{array}{l}\text { Possibilidade de atuação } \\
\text { internacional, principalmente } \\
\text { no MERCOSUL. }\end{array}$ \\
\hline
\end{tabular}

Fonte: Elaborado pelo autor.

As principais divergências sobre os rumos do setor entre os dois blocos políticos que governaram o país no período - PSDB e PT - estiveram, sobretudo, na estrutura de mercado (monopólio versus liberalização) e suas consequências organizacionais (tipo de corporatização).

Do ponto de vista das estratégias políticas para o setor postal, portanto, há uma diferença entre os blocos políticos que ocuparam o governo federal no período. No entanto, ela subsume diante das ferramentas gerenciais adotadas. 